\title{
A 10-year follow-up service evaluation of the treatment pathway outcomes for patients in nine in-patient psychiatric rehabilitation services - ERRATUM
}

Tom Edwards, (1) Alan Meaden, Martin Commander

BJPsych Bulletin (2023) 47, 63, doi:10.1192/bjb.2022.8

(c) The Author(s), 2022. Published by Cambridge University Press on behalf of the Royal College of Psychiatrists. This is an Open Access article, distributed under the terms of the Creative Commons Attribution licence (https://creativecommons.org/licenses/by/4.0/), which permits unrestricted re-use, distribution, and reproduction in any medium, provided the original work is properly cited.

DOI: https://doi.org/10.1192/bjb.2021.123, Published by Cambridge University Press, 11th January 2022.

Keywords Rehabilitation; schizophrenia; psychotic disorders; outcome studies; in-patients.

The first author's name was incorrectly published in the above article. This has since been corrected. The Publisher apologises for the error.

\section{Reference}

1 Edwards, T, Meaden A, Commander M. A 10-year follow-up service evaluation of the treatment pathway outcomes for patients in nine in-patient psychiatric rehabilitation services. BJPsych Bull 2022; 1-5. doi: 10.1192/bjb.2021.123. 